\title{
A planner's perspective on the health impacts of urban settings
}

\section{Susan Thompson}

Planning and Urban Development Program, Faculty of the Built Environment, University of New South Wales Email:s.thompson@unsw.edu.au

\begin{abstract}
The profession of town planning originated out of concerns for the health and wellbeing of people. Progress was made as crowded and unsanitary inner city slums were replaced with suburban environments where individuals could access green open spaces and clean air. With significant increases in urban populations and the geographic spread of the city, over time these environments became increasingly unhealthy. This paper provides an overview of how modern urban environments impact on people's physical and psychological health. This understanding will assist planners and health professionals to ensure that HIA and other related impact assessment tools are effective in identifying and ameliorating potential adverse well-being outcomes of different urban policies and proposals for varying scales of development.
\end{abstract}

The links between town planning and health go back to the origins of town planning. The creation of zoning to separate dirty, polluting uses of land from the places where people lived was an important public health initiative. While it may not have been explicitly expressed as such, inherent in this approach was a clear connection between the health of communities, the environment and urban planning. And while planning has continued to address environmental issues that positively contribute to wellbeing, a specific focus on health has, until recently, taken a back seat.

Understanding exactly how different urban settings affect well-being is an important step in bringing planning and health closer together. Starting with planning's historical links with public health reform, this paper provides an overview of how different urban settings affect physical and mental health - from the far-flung suburbs to the inner city. The situation is complex: indeed, both inner and outer urban environments have implications for health and wellbeing. These implications need to be better understood so that health impact assessment (HIA) and related processes, such as environmental and social impact assessments, are more effective. These tools, used alone or in combination, can enhance the identification of potential health impacts before a development approval is granted or a planning policy finalised making cities healthier places for all.

\section{History of town planning's origins in health}

Early definitions of town planning reveal that the health of the community was a key objective of the fledgling profession. Sir Patrick Abercrombie, an influential English planner in the early 20th Century, described the principles of planning quite simply as beauty, health and convenience. And while beauty came first in his list, it was 'the quality which must run through the whole in order to lift sanitation and engineering to the level of civic design and the dignity of city life'. ${ }^{1}$ Australian planners also saw the achievement of a healthy community as central to their work. In practical terms, concerns for the health of city inhabitants - particularly those living in overcrowded inner-city slums - stimulated the development of two principles that have dominated planning ever since: the concept of zoning and that of the suburb.

Zoning plans focussed on separating dirty and polluting uses, such as factories, from clean uses, such as residential and recreational areas. Known as land-use zoning plans, these schemes assumed that planning activity could rationally order and control land use and development. The suburb was typified as the best place to bring up families in wholesome and healthy circumstances away from the squalor and poverty of the densely packed inner city. ${ }^{2}$ Post World War II housing programs boosted suburban development and the availability of the motor car further stimulated suburban expansion. ${ }^{3}$

As cities grew, so did the geographical extent of the suburb, along with the separation between home and work. This situation has become increasingly problematic for human health; planning must now return to one of its original objectives - that of enhancing public health.

\section{The impact of urban settings on health The suburban setting}

The suburb initially offered a quiet and healthy living environment separated from working areas, typically 
characterised by polluting industries. But as city populations increased and cleaner industrial processes were introduced, the need for a large geographical separation between housing and places of employment diminished. Today, it is the very separation that is causing a problem for the physical and mental health of communities. ${ }^{4}$

The positioning of different land uses in a city, and the ways in which they are inter-connected, significantly influence how individuals travel from their homes to work, school, shops, recreational areas and other public facilities. In Australia, suburbs have generally been developed with low-density residential forms - typically a house on its own block of land - and poor public transport infrastructure. Street subdivisions are characterised by convoluted cul-de-sacs rather than the traditional street grid.
While the former might make for a safer street - neighbours looking out for each other and little through traffic enabling children to play on the road - these subdivision patterns do not encourage walking. It takes longer to get between places because the convoluted road networks mean that the actual distance travelled is much greater.

The high level of car dependency in suburban localities has significant health and well-being implications. Retail facilities, particularly stand alone shopping centres, are designed with the car user in mind, are generally poorly connected to public transport and can be unfriendly to pedestrians. As parents worry more and more about their children's safety, both from the real and perceived dangers of strangers and vehicles, youngsters do not walk to school or play games outdoors. People who commute long dis-

Table 1. Connecting health and planning

\begin{tabular}{|c|c|c|}
\hline Health objective & Current concerns & How can planning assist? \\
\hline Healthy lifestyles & $\begin{array}{l}\text { Sedentary, stressful and isolated lifestyle are } \\
\text { factors in conditions such as heart disease, } \\
\text { stroke and depression }\end{array}$ & $\begin{array}{l}\text { Physical environments which provide attractive and } \\
\text { appropriate open space; make it easy and enjoyable to } \\
\text { walk to local facilities, catch public transport and } \\
\text { connect with people }\end{array}$ \\
\hline $\begin{array}{l}\text { Social cohesion } \\
\text { (sense of belonging) }\end{array}$ & $\begin{array}{l}\text { Isolation from human interaction and } \\
\text { friendship networks contribute to } \\
\text { depressive conditions; separation of } \\
\text { communities }\end{array}$ & $\begin{array}{l}\text { Safe environments, attractive and well used public } \\
\text { spaces, culturally appropriate spaces and mixed uses } \\
\text { encourage human interaction, social cohesion and } \\
\text { sense of belonging }\end{array}$ \\
\hline $\begin{array}{l}\text { Housing quality } \\
\text { (importance of } \\
\text { home) }\end{array}$ & $\begin{array}{l}\text { Poor housing and homelessness - lack of } \\
\text { adequate and appropriate physical shelter } \\
\text { contributes to poor physical and mental } \\
\text { health }\end{array}$ & $\begin{array}{l}\text { Good individual housing design; housing mix - type } \\
\text { and tenure; affordable housing; importance of 'home' in } \\
\text { self actualisation and creating a sense of well-being and } \\
\text { belonging to a community }{ }^{10}\end{array}$ \\
\hline Access to work & $\begin{array}{l}\text { Unemployment leads to financial stress } \\
\text { which has severe and comprehensive } \\
\text { health implications }\end{array}$ & $\begin{array}{l}\text { Planning and economic policy linkages; provision of } \\
\text { local and accessible employment opportunities }\end{array}$ \\
\hline Accessibility & $\begin{array}{l}\text { Poor accessibility encourages car } \\
\text { dependencyand resultant inactivity health } \\
\text { problems; high air pollution has serious } \\
\text { health implications }\end{array}$ & $\begin{array}{l}\text { Physical environments which make it easy, safe and } \\
\text { enjoyable to walk to local facilities and catch public } \\
\text { transport (which must be cheap and abundant); } \\
\text { provision of cycle ways as viable transport options; traffic } \\
\text { calming }\end{array}$ \\
\hline $\begin{array}{l}\text { Local, low-input } \\
\text { food production }\end{array}$ & $\begin{array}{l}\text { Inadequate access to cheap, healthy and } \\
\text { culturally appropriate food leads to } \\
\text { consumption of high energy'fast' foods - } \\
\text { linked to obesity; especially problematic for } \\
\text { disadvataged communities }\end{array}$ & $\begin{array}{l}\text { Provide opportunities for community gardens and fresh } \\
\text { food markets; retain small-scale farms and gardens; } \\
\text { provide for a mix of food retailers in local shopping } \\
\text { centres; good use for private yards }\end{array}$ \\
\hline Safety & $\begin{array}{l}\text { High volumes of traffic cause death and } \\
\text { serious injury; also dissuade people from } \\
\text { exercising as do concerns for personal safety } \\
\text { - over use of the car increases physical } \\
\text { inactivity and resultant health problems }\end{array}$ & $\begin{array}{l}\text { Traffic calming and provision of good public transport; } \\
\text { provision of safe walking routes and programs for } \\
\text { children's journey to school; implementation of Crime } \\
\text { Prevention through Environmental Design (CPTED) } \\
\text { principles }\end{array}$ \\
\hline Equity & $\begin{array}{l}\text { Living in poverty results in physical and } \\
\text { psychological deprivation; poor access to } \\
\text { health facilities; high disease rates and } \\
\text { premature death }\end{array}$ & $\begin{array}{l}\text { Low cost housing; accessible local community facilities; } \\
\text { local job opportunities; provision of environments that } \\
\text { encourage interaction and connection }\end{array}$ \\
\hline $\begin{array}{l}\text { Air quality and } \\
\text { aesthetics (protection } \\
\text { from pollution, noise; } \\
\text { provision of attractive } \\
\text { environments) }\end{array}$ & $\begin{array}{l}\text { Air and noise pollution cause serious disease } \\
\text { - breathing difficulties and possibly asthma; } \\
\text { loss of hearing; unattractive and polluted } \\
\text { environments contribute to inactivity }\end{array}$ & $\begin{array}{l}\text { Provision of reliable, cheap, safe and abundant public } \\
\text { transport; reduce car dependency; ensure good design } \\
\text { in public spaces; encourage low level energy design } \\
\text { (ie sustainable development) }\end{array}$ \\
\hline
\end{tabular}


tances from home to work often do not have the time or energy to form meaningful relationships with neighbours. Similarly, family relationships can suffer from long absences from home. Commuters also have less time to spend using local healthy planning innovations such as cycleways and walkable neighbourhoods. The net result is reduced community interaction and social capital.

But it is wrong to characterise the suburb as being all bad for health. In particular, the backyard is a healthy resource. It is safe for active children's play and readily accessible on a daily basis. Private yards, where gardens grow, provide fresh fruit and vegetables which are both economical and culturally appropriate. ${ }^{5-7}$ These spaces also provide opportunities for regular and enjoyable physical activity. Families can socialise there, and have pets, which bring many recognised health benefits to humans. ${ }^{8}$

\section{Consolidated city settings}

In contrast to the suburb, denser, inner residential areas increasingly characterise Australian cities. These environments are rightly lauded for their walkable local destinations, proximity of living and working areas, plentiful and easily accessible recreational and cultural facilities, together with good public transport infrastructure. Consolidated inner localities epitomise the objectives of sustainable city planning with its focus on high residential densities and lower levels of car dependency. However, while these areas have significant health benefits, there are problems that need to be acknowledged. Heavily trafficked, polluted, unsafe and unpleasant environments do not promote walking. It is difficult to access local food production opportunities, and cheap, healthy and culturally appropriate food can be hard to source. For disadvantaged communities, this can lead to the consumption of high energy fast foods, which are in turn linked to obesity and other adverse health conditions.

Redevelopment of the inner city has increased housing costs, ${ }^{9}$ forcing those without the necessary financial resources into poor or inadequate accommodation, and in extreme cases, homelessness. And for those able to afford to live in the inner city, body corporate rules and regulations can result in a reduction of personal autonomy and power at home. ${ }^{10}$ Pets, for example, are often prohibited from high rise apartments.

Less readily accessible open space for active children's play is another adverse health consequence. A welldesigned park may be part of a residential apartment complex, but if overly controlled it can dissuade some users and, for those living high above the ground, easy access for children is not an option. Increased energy use in high-density developments also raises health concerns. Air conditioning systems, clothes driers and lifts, commonly installed in high rise buildings, can increase green- house gases, in turn adversely affecting the climate and well-being of entire populations. ${ }^{11}$

\section{Summary}

Urban settings have different impacts on human wellbeing. A complex picture is revealed which necessitates a sophisticated understanding of the health implications of both low- and high-density urban forms. This understanding is particularly important for those undertaking HIA or related impact assessments on proposals for urban policy, as well as applications for specific developments - from single sites to entire neighbourhoods and regions. Table 1 summarises the relationship between health objectives and the ways in which good urban planning can contribute positively to community well-being. ${ }^{12}$

\section{Planning and the HIA process}

With an understanding of how different urban environments affect well-being, planners are in a position to assess the health implications of proposed plans and developments before they are enacted or approved. The consideration of specific health impacts is becoming increasingly important as planners are reacquainted with the promotion of health as a core component of their work. Together with their existing knowledge of the environmental and social impact assessment processes, planners are in a good position to make positive contributions to the HIA process. ${ }^{13}$ Adverse impacts of different proposals can be identified before implementation and changes made to the policy or development to ensure that the eventual outcome will support healthy behaviour of individuals and entire communities.

\section{Conclusion}

Health professionals and planners are beginning to see the benefits of working together. Many are realising that this is the only way forward to address the serious lifestylerelated health problems in contemporary communities. While working across professional and disciplinary boundaries is proving difficult, it is critical that we find pathways to connect planning and health. An understanding of how different urban settings impact on health is an important first step.

\section{References}

1. Abercrombie P. Town and country planning. 3rd ed. London: Oxford University Press, 1959.

2. Alexander I. The post-war city. In: Hamnett S, Freestone R, editors. The Australian metropolis: a planning history. St Leonards: Allen and Unwin, 2000.

3. Mumford L. Suburbia and beyond. Chapter $16 \mathrm{In}$ : The city in history: its origins, its transformations, and its prospects. Harmondsworth: Penguin Books, 1961.

4. Frumkin H, Frank L, Jackson R. Urban sprawl and public health: designing, planning and building for healthy communities. Washington DC: Island Press, 2004. 
5. Bartolomei L, Corkery L, Judd B, Thompson S. A bountiful harvest: community gardens and neighbourhood renewal in Waterloo, Sydney. Sydney: NSW Department of Housing and the University of NSW, 2003.

6. Gleeson J, Hamilton M. Marrickville backyards. Sydney: Marrickville Community History Group, 2001.

7. Thompson S, Corkery L, Judd B. The role of community gardens in sustaining healthy communities. Paper to be presented at the Third State of Australian Cities Conference, Adelaide, November 2007.

8. Jackson V. People, pets and planning. Australian Planner 2007; 44: 6-7.

9. Searle G. Sydney's urban consolidation experience: power, politics and community. Research Paper 12. Brisbane: Griffith University, Urban Research Program, 2007. Available at www.griffith.edu.au/centre/urp, accessed 31 July 2007.
10. Thompson S. Meanings of home: developing a responsive and humane planning practice. Plan Canada 2002; 42: 13-15.

11. Randolph B, Troy P. Energy consumption and the built environment: a social and behavioural analysis. Research Paper 7. Sydney: University of NSW, City Futures Research Centre, 2007. Available at http://www.fbe.unsw.edu.au/ cityfutures/publications/researchpapers/researchpaper7.pdf, accessed 24 August 2007.

12. Barton $\mathrm{H}$, Tsourou C. Healthy urban planning: a WHO guide to planning for people. London: Spon Press on behalf of the World Health Organisation Regional Office for Europe, 2000.

13. Kemm J, Parry J, Palmer S. Eds. Health impact assessment: concepts, theory, techniques, and applications. Oxford: Oxford University Press, 2004. 